\title{
The Premiere of L'Annonce faite à Marie in the Context of Heightened Interest in the Middle Ages and Jeanne d'Arc
}

\author{
Carolyn Snipes-Hoyt \\ Pacific Union College
}

In 1912, the year that Claudel's L'Annonce faite à Marie premiered, was the same year the five hundredth anniversary of Jeanne d'Arc's birth was celebrated in France. Given the heightened interest in the Middle Ages that occurred in the late nineteenth-century, it would make sense to consider the play from the angle of its medieval setting and its featuring of Jeanne d'Arc in Act III, a significant moment in the plot.

The setting of this play is not the "real" Middle Ages in decline, but rather a conventional fifteenth century, as stated in the stage directions at the beginning of the "Première version": "Tout le drame se passe à la fin d'un Moyen Age de convention, tel que les poètes du Moyen Age pouvaient se figurer l'antiquité" (11). ${ }^{1}$ Events and historical figures are mentioned whose dates barely overlap, if at all. An early reference in the play (Act I, scene 1) brings together the French Dauphin as child (born in 1403 and future Charles VII), Henry V of England (1387-1422), and the Great Schism, which ended in 1417, when Jeanne d'Arc was about five years old, Charles fourteen, and Henry thirty-hardly an infant: ${ }^{2}$

A la place du Roi nous avons deux enfants.

L'un Anglais, dans son île,

Et l'autre si petit qu'on ne le voit plus, entre les roseaux de la Loire.

A la place du Pape, nous en avons trois et à la place de

Rome, je ne sais quel concile en Suisse. $(30)^{3}$ 


\section{Carolyn Snipes-Hoyt}

The condensation of these events and personages in the play creates a chronology that is "beyond" the events, as Dessaintes has noted (81), thereby multiplying the levels of signification that build toward the climax of the play: the point where Violaine resuscitates her sister Mara's infant daughter, Aubaine. I would like to put forward the idea that additional weight and meaning is given to the action of the play by this concentration and distortion of major late medieval events and themes, such as saints, pilgrimage, and the Gothic cathedral. In particular, the emphasis on Jeanne d'Arc's story develops a parallel to Violaine's, highlighting layers of symbolic meaning associated with this central character, in the context of its first performance in December of 1912.

The medieval heroine accompanied the Dauphin to Reims to be crowned in the cathedral on the $17^{\text {th }}$ of July, 1429 , not on Christmas Eve, as is the case in Claudel's play, where there is also mention of King Clovis, who, according to the legend, found himself in Reims on Christmas day for his baptism (65). Even in July of 1429, it was later reported in the Procès de réhabilitation, that locals met the Dauphin with cries of "Noël" when he entered Reims and the congregation shouted out "Noël!" at the end of the actual ceremony when the crown was placed on his head (Pernoud/Clin104-106).4 The winter atmosphere of "Noël" in Act III of Claudel's play seems relevant, not only given this first performance on December 20,1912, but also, in a round-about way, a purposefully orchestrated echo of the "Noël!" shouted out at the actual coronation of Charles VII. The importance of this Christian holiday for Claudel personally is well-known, since he dated his conversion from the Christmas of 1886, when he attended vespers at the Notre-Dame cathedral in Paris (Autrand 204). Another misrepresentation of the play would have the Dauphin and his entourage passing through the Tardenois region of France (called "la Chevoche" in the play) before the coronation, whereas in actuality he would have traversed this area afterwards (Autrand 231).

Although the premiere of L'Annonce took place late in 1912, festivities honoring the medieval heroine Jeanne d'Arc had 
begun on January 6, since Epiphany has traditionally been assigned as the date of her birth, another part of this legend mentioned in the play. ${ }^{5}$ This year-long birthday celebration, combined with the homage that had been offered for her beatification three years before, in 1909, resulted in an increase in publication on Jeanne d'Arc and a proliferation of works of art with her as their subject. The Catholic Church, after its complicity with the English in ensuring the young woman would be burned at the stake in 1431, had come full circle and would now make official this young martyr's sainthood, since she had been revered by the common people from the beginning of her mission.

In fact, the volume of production on Jeanne d'Arc was at its highest point ever during these pre-World War I years. In particular, the heroine served as a rallying point for the political factions of the right, who aligned themselves with her for a number of reasons, but it was, principally, her adherence to traditional French institutions they wished to promote: patriotism, the Catholic religion, the monarchy, and the military. For the political conservatives, the figure of Jeanne d'Arc represented, first of all, everything that liberal, anti-clerical France had destroyed. She was placed in opposition to figures such as Voltaire, whose centenary in 1878 had created the impetus for putting Jeanne d'Arc's canonization process in motion. ${ }^{6}$

The Dreyfus Affair had been a flamboyant and more recent reminder of encroaching internationalism (and the Jewish element in particular), seen by the conservative elements in French society as a threat to traditional French values; this situation had ignited in January of 1898 with Émile Zola's publication of "J'accuse...!" in L'Aurore, and the furor continued through the first decade of the twentieth century and beyond.? Other factions of political discourse further to the left felt that conceding to the call for a national holiday in honour of "la Pucelle," would be giving in to the Catholics and the conservative factions. Church and State had been officially separate since 1905 and an effort was needed to keep them apart, it was felt by those who supported the Third Republic's secularist stance. ${ }^{8}$ 


\section{Carolyn Snipes-Hoyt}

The various facets of the Jeanne d'Arc figure that appealed to the conservatives were in harmony with the three levels represented in Claudel's play, as Dessaintes has noted: the local or familial level, since Jeanne d'Arc's origins were French and humble; the national level, since Jeannne d'Arc's vision took in the various regions of France as one political entity, separate from England; the Catholic level, as Jeanne d'Arc was an ardent believer, following visions and the voices of her saints and practicing all the rituals of the Church (86). Furthermore, she fit in perfectly with Claudel's homely dramatis personae, a farm family breaking bread in Act I-their last gathering until the tragic ending, when the beloved daughter Violaine dies (42). ${ }^{9}$

By 1912, the year of the premiere of L'Annonce faite à Marie, positive interest in the figure of Jeanne d'Arc broadened to include most of the political spectrum. In July of 1911, there had been a failure in the negotiations for a Franco-German exploitation of Morocco, signaling deterioration in French-German relations that did not result in panic, but this event mobilized French patriotism, according to Eugen Weber $(93,95)$. Debate reopened in the French Parliament in May of the next year, 1912, with Raymond Poincaré as "président du Conseil," on the institution of a national holiday to honor the heroine and the bill found more general support than before. ${ }^{10}$

During the pre-war years, these events and arguments contributed to the extraordinary output of cultural production with the heroine as its subject. There were boy scout troops called "Jeanne d'Arc"; prayer books, engravings, newspaper and magazine articles, advertisements, and historical works were published depicting Jeanne d'Arc; performances took place, such as public demonstrations and speeches, lesser dramatic productions, including a play by Jules Baudot staged in Domremy for pilgrims visiting Jeanne's birthplace, and sermons preached; in anticipation of this year, statues, frescoes, mosaics, and stained-glass windows were designed or created with the heroine as their subject, many of these destined for the new Basilica built in her honor in Domremy. ${ }^{11}$ 
The first of the major dramatic works that have since been recognized and consecrated as "French Literature" were published by 1912 , but were not widely known and certainly were not presented on stage until much later. These plays were written by Charles Péguy, who, like Paul Claudel and a few others, had returned paradoxically to their Catholic roots during the height of success of the secularist Third Republic. Péguy had completed a series of plays on the heroine from a socialist perspective in 1897; after his conversion in 1907, he began his second series of plays on the heroine in 1910, the so-called Trois Mystères, completing the cycle in 1912 with Le Mystère des saints innocents, about Jeanne d'Arc and Saint Louis. Later in 1912, Péguy inaugurated a series of poetical works, Les Tapisseries, and the first of these published was Les Tapisseries de Sainte Geneviève et de Jeanne d'Arc (December 1912).12 Two others of the important fin-de-siècle converts to Roman Catholicism were also interested in Jeanne d'Arc, and wrote about her: notably, Joris-Karl Huysmans in Là-bas (1891) and Maurice Barrès, whose tireless efforts on the political front ensured that the national holiday in her honor would finally be fully instituted in the 1920s. ${ }^{13}$

In the works of all four of these men-Claudel, Péguy, Huysmans, and Barrès-one notices a preoccupation with three other aspects of the Middle Ages that figured prominently in both popular and elite culture of the time-the lives of saints, the Gothic cathedral, and pilgrimage-, and these areas are also relevant for L'Annonce faite à Marie. ${ }^{14}$ They captured the French imagination during the last part of the nineteenth century and remained a prominent part of the social discourse during the first decades of the twentieth. After a brief discussion of these medieval topics that form the discursive context of L'Annonce and its first performance, I will return to a few specifics of the actual premiere of Claudel's play and the comparison of two of its female personages, Violaine and Jeanne d'Arc.

In post-Revolutionary France, the desire for spiritual renewal associated with saints can be traced to the reinstatement of Catholicism during the Napoleonic era, as Elizabeth Emery has 


\section{Carolyn Snipes-Hoyt}

noted (Medieval Saints 4). Jules Michelet is perhaps most responsible for creating the model of saint's life that became popular, with the publication of two chapters on Jeanne d'Arc (1841) in his Histoire de France, showing her courage and heroism in the face of adversity and comparing her death to Christ's, according to JeanLouis Cabanès (30). The two chapters on Jeanne d'Arc were published subsequently as a monograph by the Bibliothèque des chemins de fer, in 1853, which went through numerous editions (Margolis 128). Actual medieval representations of saints found in Gothic cathedrals-statues, bas-relief sculptures, stained-glass windows, etc.-had also inspired nineteenth-century novelists, poets, and dramatists in the category of elite literature, starting with Gustave Flaubert. ${ }^{15}$ Near to the turn of the twentieth century, interest in saints shifted from the field of religious devotion and popular entertainment to avant-garde circles. Their representation continued to be common in churches or religious sites, but they also appeared in cabarets, Symbolist poetry and plays (Emery, Medieval Saints 1-2). ${ }^{16}$ In Claudel's play, Violaine takes on the aura of a saint, principally as a result of her suffering and self-sacrifice.

With World War I looming on the horizon, "saints" were openly applauded for their patriotism and figures such as Saint Geneviève, Jeanne d'Arc, Saint Louis, who were well-suited to this role, became especially prominent. Painted scenes from the lives of these figures were added to the Pantheon in Paris in the late nineteenth century, and their representations were added to the decorative scheme of the Sacré Coeur, the construction of which continued until 1914.17 The featuring of these saints in Péguy's Mystères and Tapisseries constitutes another example of the tenacious fusion of patriotism and religious faith that has become a French tradition dating back to the Chanson de Roland.

Pilgrimage, often closely connected to the "saint phenomenon," was evoked in both Zola's and Huysmans' novels about Lourdes (1894 and 1906) and provided a major component of Claudel's play, as a motivation for Anne Vercors' departure. In Act I, Violaine's father is leaving his home to go on a journey to the Holy Land, in an anachronistic suggestion of the Crusades, and 
hopes to leave the family farm in the care of his recently appointed son-in-law, Jacques Hury. Commonly regarded as a manifestation of medieval spirituality, pilgrimages again drew crowds in France during the last half of the nineteenth century and on into the twentieth, as is well known, notably in connection with the movement of the Sacré-Coeur, which was to bring renewal and atonement to a suffering nation, and with the healing powers attributed to the waters of Lourdes. Pilgrimages entailed the production and marketing of objects of worship and industrialization brought on a surge of printed material, including images, similar to those produced in Épinal, and mass-produced statuettes (Emery, Medieval Saints 4).

Finally, the Gothic cathedral itself figures prominently in Claudel's L'Annonce, especially in connection with the character Pierre de Craon, the builder of cathedrals. ${ }^{18}$ Additionally, the appearance in Act III of Jeanne d'Arc and the Dauphin, on their way to the coronation in Reims, is a specific reference to an important French Gothic cathedral, but the architect and builder of cathedrals mentions others as well. Indeed, Pierre de Craon connects the notions of pilgrimage and cathedral, constantly in motion as he is, attached neither to family nor to home, working on aspects of various churches. Seeking spiritual renewal and healing, Craon makes a trip to the Holy Land himself and meets Anne Vercors there. The Gothic cathedral had in fact become a renewed topic of concern and discussion in France, before and after the official separation of Church and State. The question was raised as to whether Church property was to be allowed to fall into disrepair and to be plundered as was the case during the Revolution.

A number of the authors mentioned above, including Huysmans and Barrès, but also Zola and Proust, concerned themselves with the fate of the Gothic cathedral in a secular Republic, valuing these monuments as repositories of medieval culture and the role they have traditionally played in creating community and fostering spirituality (Emery, Romancing the Cathedral 170). The project of saving and appreciating French Gothic cathedrals can be traced in French literature back to Victor Hugo's Notre-Dame de 
Paris (1831) and further back to Chateaubriand's Génie du Christianisme (1802), which contained a chapter entitled "Des églises gothiques."

In 1910, when Claudel began work on the new version of La Jeune Fille Violaine (written in 1892 and revised in 1899) that was to become L'Annonce, he incorporated the medieval setting, among other changes. ${ }^{19}$ The result was the first version of L'Annonce faite à Marie, not only Claudel's first play to be performed but also regarded as his most famous play, and often the only one known. The new title of the play evoked all the ancient paintings from the Middle Ages that show the rustic Virgin Mary wearing a halo as the angel brings her the news of the Holy Child that will be hers, as Autrand has noted (9-10). In connection with the story of Violaine, the title is enigmatic, open to a number of interpretations. The abundance of liturgy used in this play, in particular "L'Angelus," supports the impression that this is an idealized story about country life, heavy with significance to be probed..$^{20}$ Its mystery and the sense of the spiritual that imbue the characters, created by the stylized evocation of their surroundings and their measured, poetic exchanges, no doubt contributed to the play's great attraction during the first half of the twentieth century and its becoming public domain during that period in Christian milieus the world over.

Claudel put forth an effort, even at the time of the premiere of his first play, to simplify both the décor and the action, advising actors to avoid exaggeration and any unnecessary movement while on stage. He opted for an iconographic acting style, with understated gestures and intonation. Nevertheless, he wanted to give a strong suggestion of the Middle Ages and so was in agreement with the stylized stage sets created by Jean Variot that were to be used in the Salle Malakoff where the first performance took place (Autrand 216, 220). Both of these considerations would contribute to achieving the "caractère assez grandiose" he had found missing in La Jeune Fille Violaine. ${ }^{21}$ These notions harmonized with the symbolist artistry of Lugné-Poe, the director of the play and founder of the Theâtre de l'Oeuvre. While Claudel felt that humble, rural 
people should play most of the roles for a story taking place in the countryside and that their conflicts and issues should be apparent to the simplest audience, he also wanted their actions to carry a wider and deeper significance than mere day-to-day routines. ${ }^{22}$

Nevertheless, Claudel refused the label of "symbolist" and disagreed in general with the current use of the word "symbol," insisting instead on the religious significance of the term. Claudel spoke out clearly on the topic of symbolism in about 1930, noting that the word "symbol" for him pointed to a deep relationship, essential, as if the two had been created one for the other, as if they owed their origins to the same word, and as if between the two there were a kind of continuity. For him, the poet is the one who perceives and translates for others this dialogue between what he terms, in French, the sensible and the intelligible. ${ }^{23}$ Claudel's insistence that the staging of his play be "conventionally" (or "stereotypically") medieval, and not historically accurate to the detail, contributed to the creation of characters that were "biggerthan-life," almost as if wearing the halos of saints. With the sets he created, Variot evidently tried to replicate the "framing" device found in paintings by Italian primitives, from the school of Sienna, where the figures are large in proportion to the architectural structures in which they appear. ${ }^{24}$

The fact that the play is set in the Middle Ages reinforces the possibility of seeing the humble characters, such as Violaine and her family, as part of a legend, a story of sibling rivalry elevated to the level of myth. As elder sister Violaine represents all that can be positive, expressed in terms of the feminine: blond, blue-eyed, sweet, joyful, and beautiful. In Act I, her father calls her "ce doux narcisse," in contrast to her sister Mara, "la noire" (27). The descriptors of dark hair and eyes are useful in concentrating the bitterness, jealousy, selfishness, and cruelty, suggested by Mara's name (Mara=amère). Her mother uses the expressions "butée" and "dure comme le fer" to identify this daughter (29). Mara herself understands the negative ways she has been contrasted with her sister: "Oh, quand vous parlez de votre Violaine, c'est du sucre, / C'est comme une cerise qu'on suce [...]/ Mais Mara l'agache! Elle est 
dure comme le fer, elle est aigre comme la cesse!" (35) As the firstborn with no brothers, Violaine represents the joy and hope of her father, Anne Vercors, who sees her as a part of himself. He says to Jacques Hury, whom he designates as his future son-in-law: "Mon âme ne se sépare point de cette âme que j'ai communiquée [celle de Violaine]. [...] Aime-la, car elle est nette comme l'or" (40). Jeanne Le Hir suggests that Violaine is depicted as a component of Anne Vercor's character, arguing that Claudel continues the imaginative logic that governs the elaboration of Catholic liturgy, where woman ("la femme"), wisdom ("la sagesse") and the Church ("l'Eglise") are equated, since all are feminine nouns in French. Furthermore, France is itself considered "la fille aînée de l'Église." 25 This use of feminine and masculine figures in the symbolism and language of the Catholic Church raises questions and encourages speculation as to the interpretation of these figures in Claudel's play.

It could be argued that Anne Vercors is put forward as a figure for God-the-Father, when he says to Violaine: "Connais, ma fille, ton père!/ L'amour du Père/ Ne demande point de retour et l'enfant n'a pas besoin qu'il le gagne ou le mérite [...]" (39-40). Vercors clearly follows ritual associated with the Pater familias, taking his seat at the head of the table and breaking the bread (42). But this role, at the last meal shared with his family before his departure, could be associated as well with Christ the Son. He formulates sentences that resemble those traditionally spoken by Christ when taking leave of his disciples: "Maintenant que je m'en vais, faites comme si j'étais là. Car je reviendrai. Je reviendrai au moment que vous ne m'attendez pas" (43). This kind of allegorical interpretation could be justified, as Jeanne Le Hir has noted in another context, since Claudel himself wrote in his Journal, in 1923:

Tout est parabole, tout signifie la complexité des rapports des créatures avec leur Créateur. C'est cette idée q[ui] pénètre toute mon oeuvre. Il n'y a rien sur cette terre qui ne soit comme la traduction concrète ou déformée du sens qui est dans le ciel. (Qtd. in Le Hir 39) 
Nevertheless, Anne Vercors is simultaneously a human father, subtly associated in a negative way with the "Loriot," since children are heard singing, in Acte I, Scène III, "Compère loriot! / Qui mange les cesses et qui laisse le noyau!" (41). Vercors has just announced that he is leaving the family at a difficult moment, and perhaps has not been entirely fair to Mara.

Following the allegorical line of inquiry, the role Violaine plays in the lives of other masculine characters requires examination. An exploration of her relationship to Pierre de Craon, the ecclesiastical architect, will be sufficient for our purposes, although her relationship to Jacques Hury, her betrothed, parallels Pierre's to a great extent. Certainly, Violaine's beauty and lightness of spirit bring joy to both. ${ }^{26}$ In the case of Pierre de Craon, the strong attraction has caused him to overstep the bounds of the acceptable, the audience learns in the Prologue. Now, he is suffering from leprosy. He explains to Violaine that she is at fault: "C'est vous qui m'avez fait ce mal par votre beauté, car avant de vous voir j'étais pur et joyeux" (23). In the exchange that follows, he calls her both "petite âme" and "image de la beauté éternelle" (23), revealing the interconnectedness of the notions of beauty, goodness, and spirit in Claudel's poetics, and their power is illustrated in the attraction between the sexes. Evil lies in succumbing, crossing the line between the spiritual and the physical, without respect for the values of family or nation.

In this regard, the image of the "alouette," or lark, elaborated in the Prologue, will be of particular interest. ${ }^{27}$ This bird serves as a motif for Violaine herself, who first of all calls Pierre de Craon's attention to one, calling it "cette petite âme qui chante" (21). Later, Violaine refers to the lark as "la petite croix véhémente, comme les séraphims qui ne sont qu'ailes sans aucuns pieds et une voix perçante devant le trône de Dieu" (21). Pierre de Craon remembers hearing a lark at dawn the day his "fille"- that is, the church he built called Notre-Dame de la Couture-was dedicated. ${ }^{28}$ It appeared as a bit of gold, appearing like a new star (21). Then Pierre de Croan calls out to Violaine, as if she is a lark"Chante au plus haut du ciel, alouette de France!" and he tells her 
"Va au ciel d'un seul trait!" confusing the image he has developed of Violaine as a bird, first with the nation, and then with that of a saint, as a hint of what it is to come (22). This meaning, that Violaine is destined for sainthood, becomes clear when de Craon remarks "Quant à moi, pour monter un peu, il me faut tout l'ouvrage d'une cathédrale et ses profondes fondations" (22). When Pierre takes leave of Violaine, it is clear that he sees her as a representation of his own soul: "Adieu, Violaine, mon âme, je ne vous verrai plus!" (24). ${ }^{29}$

In the fifteenth century, a seventeen year-old country girl, full of energy and joy, began her mission to contribute to the cause of the French, buoying up the souls of those fighting for the dream of a French nation separate from England. In L'Annonce, it is the simple people preparing for the arrival of Charles and Jeanne for the coronation, who express the joy associated with the astounding accomplishments of this "simple fille" who had been watching her father's cattle only six months before (65). Both Jeanne d'Arc ("fille de Dieu") and Violaine ("fille d'Anne Vercors") are representatives of a feminine force that will enable men to attain their goals. Claudel's drawing of a parallel between Violaine with Jeanne d'Arc intensifies the contributions of both, so that their extraordinary human spirits could be seen, within the religious framework of the play, as representing the Holy Spirit or a kind of "invisible church," in other words, the non-material, positive aspect of faith.

In Act IV, Scene V of the play, the Violaine and Jeanne d'Arc come together once again, in death. Anne Vercors intones a recital of those who are now gone: "Ma femme aussi/ Est morte, ma fille est morte, la sainte Pucelle/ A été brûlée et jetée au vent, pas un de ses os ne reste à terre" (105). For Claudel and other adherents of the Roman Catholic Church, however, the suffering and sacrifice of one can atone for the mistakes and pains of others and thereby bring about regeneration. The idea that suffering precedes renewal permeates this play and, paradoxically, that sainthood can only be achieved through an encounter with Evil..$^{30}$ The figure Violaine carries the symbolic value of all that is charitable and good in this life, yet she must experience and submit to the ugli- 
ness of misfortune and disease, experience rejection, and bear the agony of exile all alone, in order to bring something positive to her family and country. Vercors ends his litany of the dead with what has been accomplished at the end of all this suffering: "Mais le Roi et le Pontife de nouveau sont rendus à la France et à L'Univers. / Le schisme prend fin, de nouveau s'élève au-dessus de tous les hommes le Trône" (105).

As we have seen, the entrance of Jeanne d'Arc in Act III of the play intensifies the extreme situation of Violaine. Conversely, we could add, Violaine's story brings an unusual understanding and appreciation of the legendary Jeanne d'Arc at this time. The creation of Violaine serves as yet another form of exaltation of Jeanne d'Arc, from a perspective that differed from the other representations, of Jeanne d'Arc, whose spirit and willingness to sacrifice were again urgently needed in France just prior to World War I. Like Violaine, the medieval heroine answered the call to leave family and friends behind and forego the life of a normal peasant woman. ${ }^{31}$ Before her life ended, she had to bear misfortunes and betrayals that ended in her unspeakably painful death by fire at the age of nineteen, while Violaine contracts leprosy in showing her forgiveness to Pierre de Craon.

During the pre-World War I period, Jeanne d'Arc became essential to various masculine discourses, for example, those of traditional religion and integral nationalism. She was referred to repeatedly during the first decade of the twentieth century as the "instrument" through which God had carried out a transformation of the land in the fifteenth century, and invoked as if she again would come in spirit to the assistance of her beloved France. As the "soul" or "spirit" of the masculine characters in the play, Violaine must forego her own earthly happiness and submit to rejection and excruciating pain, in order to carry out the miraculous resuscitation of Aubaine, whose new life figures healing and renewal, as suggested by her name.

To conclude, Claudel's transposition of the story of Violaine to the Middle Ages laid the foundation for the creation of a Mystery play. The characters gain stature when placed within a 
framework of important medieval spiritual and national phenomena, elevating the story of conflict within a peasant family to the level of myth or allegory. An atmosphere is created that mesmerizes the viewer: actors move in a stylized choreographed fashion, enlarged against a spare stage setting and framed under arches; their words are intoned in a language that bears a peculiar resemblance to the occasional liturgical readings and songs that are interspersed in the text. Even Antoine (1858-1943), founder of the Thêatre libre, wrote in his Journal, after attending the premiere: "L'Annonce, de Paul Claudel, produit une très haute sensation d'art" (Qtd. in Autrand 216). With his "Moyen Age de convention," Claudel created a play with wide appeal for at least fifty years, resulting in its becoming almost a cliché, as Autrand has noted (7), a medieval Mystery in the tradition of Everyman.

In 1912, however, members of the theater audience were encouraged to leave off skepticism at the resurrection of a dead child and the miraculous change in the color of her eyes to match those of her savior. Violaine's story provided the impetus for the revitalization of the land and the family, through a breathing of the spirit of Jeanne d'Arc into the spectators themselves. In following the story of Violaine's optimism, in spite of great suffering, distilled to its essence by the presence of Jeanne d'Arc, the spectators were incited to savor medieval spirituality as a community. They could witness and empathize with all aspects of a saintly life, including a miracle that resembled those individual healings reported at Lourdes, as preparation for the suffering and sacrifice the conflict with Germany would bring.

\section{Notes}

1 All references to the "Première version" of the play will be to the Gallimard edition (1965), edited and presented by Jacques Madaule and Jacques Petit. However, the play was first published in the Nouvelle Revue française in December of 1911 and in January, March, and April of 1912. The premiere took place, on December 20, 1912, 
in the salle Malakoff, under the direction of Lugné-Poe who founded the Thêâtre de l'Oeuvre. See Madaule and Petit (1382, 1384 and 1387). In this paper, I will also refer often to Michel Autrand's invaluable introductory texts and commentaries, published by Gallimard (1993), in the paperback edition of the "Version definitive pour la scène" [1948]. Concerning the above information on the first performance of the play, see also Autrand, "Historique et poétique de la mise en scène" (216).

2 These dates are given in Le Robert. Dictionnaire d'aujourd'hui, ed. Alain Rey (1992).

3 Adams has noted that a council was established in 1415 to end the Schism. This council came to be as a result of an alteration in the constitution of the church specifically introduced to resolve the scandal of three popes claiming legitimacy. Roman papacy was restored, with the election of a native Roman of ancient lineage, Martin V (1417-1431). One such council met in Constance, on the upper Rhine, between 1414 and 1417; another met in the nearby city of Basel, between 1431 and 1437 (Adams 5).

4 Eminent medievalist and specialist in Jeanne d'Arc, Régine Pernoud co-authored this important work, entitled Jeanne d'Arc (1986), with Marie-Véronique Clin, to which I refer here and elsewhere in this paper. Jeremy Duquesnay Adams revised the work and translated it into English, publishing the new version in 1998, just after Pernoud's death in the same year. Régine Pernoud established the Centre Jeanne d'Arc in Orléans, a city that has revered the heroine since she orchestrated the lifting of the siege in 1429. I am indebted to the Centre Jeanne d'Arc in Orléans for its generosity in allowing me to use its extensive holdings in my research. Concerning the Dauphin's stop in Reims for the coronation, see also Autrand, "Notes" (231).

5 See Pernoud/Clin (391). Epiphany, as Jeanne d'Arc birthdate, is mentioned in the play by simple peasants, in Act III, Scene 1, preparing for the arrival of the Dauphin and Jeanne: "Jeanne, qu'on l'appelle"| "La Pucelle!"/ "Qu'est née la nuit de l'Épiphanie!" (65).

6 What rankled the far right was not only Voltaire's anti-clerical stance in general, but also the fact that he had written a major French work 


\section{Carolyn Snipes-Hoyt}

on the heroine, a mock-herioc poem ridiculing "la Pucelle" for her insistence on remaining a virgin, according to Philippe Contamine (408), another eminent historian of the Middle Ages.

7 In fact, according to Michel Winock, "les antidreyfusards font de la haute figure de Jeanne un archétype du nationalisme français, l'antipode de Dreyfus" (147).

8 Essayist-philospher Émile-Auguste Chartier (1868-1951) is an example of this secularist stance. He regularly published "Propos" on various topics under the pseudonym "Alain," including a couple on Jeanne d'Arc and the question of instituting a national holiday in her honour. See my doctoral thesis (416-419).

9 The stage set at the beginning of Act I reads as follows: "La cuisine de Combernon, vaste pièce avec une grande cheminée à hotte armoriée, une longue table au milieu et tous les ustensiles, comme dans un tableau de Breughel" (26).

10 For a summary of the "projet de loi" to institute a national holiday in honor of Jeanne d'Arc, see Gerd Krumeich (211-212).

11 Many examples of the popular 1912 representations of Jeanne d'Arc are commented in my thesis. According to Pierre Marot, plans for constructing the Basilique du Bois-Chenu, next to Domremy, were conceived in 1877. The main structure and many of its decorations were completed by World War I, when work was interrupted, only to be taken up again throughout the 1920s. Domremy became an important pilgrimage site during the first decades of the twentieth century (101-106).

12 See Nadia Margolis' bibliography ( 345-348). See also Lagarde et Michard (6:139-176) for an introduction to Péguy, his thought, and his works on Jeanne d'Arc. Péguy, a native of Orléans, and Claudel both appreciated Jeanne d'Arc, but for different reasons which I hope to explore in another paper. François Angelier claims that Jeanne d'Arc was the only figure Claudel found to be a worthy rival for Rimbaud. He explains: "L'une a sauvé la France, l'autre le français; l'une le sol, l'autre la langue" (36). Long after Péguy's death on the front in 1914, Claudel was to write Jeanne d'Arc au bûcher (1937), an 
oratorio with music by Arthur Honneger that was first performed on May 6, 1939, at the Théâtre municipale d'Orléans (Margolis 337). In 1948, a performance of Charles Péguy's Jeanne d'Arc was to precede L'Annonce at the Théâtre Hébertot, a situation protested by Claudel (Autrand 218).

13 For more information concerning Maurice Barrès and his efforts to honor Jeanne d'Arc, see my essay listed in "References." Barrès also wrote the introduction to Jules Baudot's play that was performed in Domremy in the summer of 1912 and published later that year. The play entitled La Vocation de Jeanne d'Arc (Bar-le-duc: Imprimerie Saint-Paul). Baudot wrote other plays about the heroine as well, including Jeanne d'Arc. Drame historique en cinq actes et onze tableaux, which came out in 1909 (Paris: Picard; Nancy: Crépin-Leblond; Reims: Michaud).

14 Regarding Barrès' and Péguy's interest in history and, in particular the Middle Ages and Jeanne d'Arc, see Marie-ClaireBancquart's book, listed in "References." She also discusses Anatole France and Léon Bloy from this angle.

15 Since Gustave Flaubert published his Tentation de Saint Antoine (1874) and his Trois Contes (1877), based on the literary genre of saints' lives ("Un Coeur simple," "La Légende de Saint Julien L'Hospitalier," and "Hérodias"), others followed suit. For discussions on the rise of interest in hagiography during the nineteenth century, see the essays by Elizabeth Emery and Jean-Louis Cabanès on Émile Zola's Le Rêve (1888), a novel about a nineteenth-century orphan who read Voragine's Légende dorée obsessively. Both essays refer as well to the impact of Flaubert's forays into the genre of hagiography and to one of this author's sources, Alfred Maury's Essai sur les légendes pieuses du Moyen Age (1843). See Emery (Medieval Saints 5 and 84) and Cabanès (27-29) Huysmans wrote his cycle of novels in which Durtal and a hermit/saint make a physical journey that parallels their spiritual quest (published from 1891 to 1903, starting with Là-bas and ending with L'Oblat), wishing to correct the lack of belief he found in Flaubert's "Saint Julien L'Hospitalier" (See Emery, Medieval Saints 84). Furthermore, and importantly for a study of Claudel's L'Annonce, 


\section{Carolyn Snipes-Hoyt}

Huysmans wrote Ste Lydewine de Schiedam (1901), using the medieval form of hagiography, with a particular emphasis on the role of expiatory suffering in the life of the eponymous Dutch woman born in 1380 (Postlewate 120). Zola featured saints, not only in Le Rêve, but in Lourdes (1892), where the story of a contemporary saint, Bernadette Soubirous, is told at length.

16 Here, Emery refers to Madhuri Mukherjee's essay: "When the Saints Go Marching In: Popular Performances of La Tentation de Saint Antoine and Sainte Geneviève de Paris at the Chat Noir Shadow Theater" (25-44).

17 The Panthéon in Paris was originally a church dedicated to Saint Geneviève in the eighteenth century. As is well-known, during and after the Revolution, it served as a temple dedicated to the "secular saints" of the French Enlightenment, such as Voltaire and Rousseau. In the late nineteenth century and the early twentieth, great men of the Third Republic were inhumed there, including Victor Hugo, Émile Zola, Léon Gambetta, and Jean Jaurès. Scenes from the lives of Jeanne d'Arc (frescoes by Lenepveu), Saint Geneviève (frescoes by Puvis de Chavannes), and Saint Louis (painting by Alexandre Cabanel) were all added in the last quarter of the nineteenth century. Gilt equestrian statues of Jeanne d'Arc and Saint Louis sit atop the entryway to the Sacré-Coeur and there are stained-glass windows, mosaics, and other works devoted to them in the interior. This information is based on personal visits to these monuments.

18 This could also be viewed as anachronistic, since the building of the Gothic cathedrals in northern France largely took place in the late twelfth century and the thirteenth and fourteenth centuries.

19 For details on the transformations that took place from the second version of La Jeune Fille Violaine to the first version of L'Annonce faite à Marie, see Jeanne Le Hir's book.

20 Autrand has noted that the final impulse for the transformation of $\mathrm{La}$ Jeune Fille Violaine into L'Annonce took place in Prague, where Claudel served as Consul from 1910 to 1911 . While in this city, he made contact with the Emmaüs convent and was impressed with the fervor of the religious ceremonies. Many of the liturgical selections he 
heard there made their way into L'Annonce at this time. See Autrand (211).

21 See Autrand (210-211 and 220-222). More details concerning Claudel's early ideas about staging for this play, for example, concerning sets and acting styles, can be found in Paul Claudel, Mes Idées sur le Théâtre. See, in particular, Petit and Kempf (7-8, 10-12); and the chapter entitled "Premiers contacts avec le Theâtre: L'Annonce faite à Marie au Théâtre de L'Oeuvre" (33-39). This latter includes Variot's notes on the stage sets he proposed.

22 Camille Mauclair, a future collaborator of Lugné-Poe, gave a definition of symbolist theater, in expressing his appreciation of Maeterlinck's dramaturgy: "Il réalisait l'idéal du théâtre, s'élever aux plus nobles conceptions métaphysiques et les incarner en des êtres fictifs pour les offrir à la méditation des artistes et des penseurs, tout en réservant à la foule le drame passionnant et parfaitement intelligible d'êtres simples où elle se devine et se retrouve." Qtd in Jeanne Le Hir (27-28).

$23 \mathrm{My}$ paraphrase. Qtd in Le Hir (28-29). The original passages follow. Note how Claudel opposed the secular definition for "symbol" given in linguistic terms:

C'est un terme de professeur, ça fait croire qu'entre le signe et la chose signifiée, il n'y a qu'une resemblance purement arbitraire et conventionnelle, tandis qu'il y a une parenté profonde, essentielle et que les deux choses ont été créées en fonction l'une de l'autre, comme si elles devaient leur origine au même mot et qu'il y eût de l'une à l'autre une espèce de continuité [...] ce beau fleuve qui coule entre les deux paradis, celui de la matière et de l'esprit, celui des sens et celui du sens, ce dialogue continuel au moyen de l'image et du reflet entre les deux rives de ce qui se passe et de ce qui dure, de ce qui est et de ce qui signifie. [...]

Le poëte est celui qui perçoit et traduit pour les autres ce dialogue entre le sensible et l'intelligible [...] (Emphasis in the original.)

24 Variot's ideas can be found in Claudel, Mes idées sur le théatre (34, and note 1). Concerning these Italian paintings, Variot explains: "Les per- 


\section{Carolyn Snipes-Hoyt}

sonnages sont grands dans le tableau, et peu nombreux pour représenter une foule. En nous basant sur cette considération, nous préférons une scène petite à une grande."

25 To take this father-daughter relationship further, Jeanne d'Arc heard the voices of her saints call her "Fille de Dieu" or "Daughter of God." See Karen Sullivan (24). Sullivan cites the deposition of Jean, the count of Dunois, the bastard son of the late duke of Orléans, at Jeanne's rehabilitation trial. He claimed that when Joan was discouraged, she would withdraw and pray to God and that when her prayer was finished, "she would hear a voice saying to her, Daughter of God, go, go, go. I will be there to help you. Go." This is a translation of a passage quoted in Pierre Duparc, ed., Procès en nullité, 5 vols. (Paris: Klincksieck, 1977-89) 1: 326.

26 There are definitely some modifications in the various "variants" and "versions" of the play in this regard. But, in the "Première version," for example, Violaine says to Jacques Hury, in Acte IV, Scène III: "Tu t'en souviens? te l'ai-je bien dit que dit que désormais tu ne m'arracherais plus de ton âme?" (91). Later, in Scène V of the same Acte, Hury laments, as a witness to Violaine's agony: "O Violaine! ô cruelle Violaine! désir de mon âme, tu m'as trahi! [...] / tes-vous donc tout à fait partie, mon âme?" (98).

27 Already, in the "première version" of La jeune fille Violaine, there is a reference to the "alouette," in the song of a child (35). Again, in Connaissance de l'est, there is the mention of an "alouette" or lark (alouette) circling higher and higher in the sky, in ever widening circles (149). There are in fact entire networks of symbolism connected to birds, flowers, and fruit in this play. Another example of bird imagery that no doubt connected to the "alouette" is the "colombe," since there is a "colombier" (or "pigeonnier") at Monsanvierge, the "saint monastère" on the hill above the farm that has been protected and supported by the Vercors family (14). This establishment is a pure invention of the dramatist, but serves as a justification for the intoning of liturgical selections throughout the play. Pierre $d$ Craon refers to the women lodging at Monsanvierge as "colombes," a reference that calls to mind the Biblical symbol for the "Holy Spirit" and a 
motif that often figures in saints' lives. It appears as though the image of the "alouette" in the Prologue of L'Annonce has been intended as a livelier, updated image of the same.

28 Pierre de Craon also refers to one of his churches as his "femme" (24).

29 In the 1950s, the image of the lark (in the play L'Alouette by Jean Anouihl) will clearly be applied to Jeanne d'Arc for similar reasons and in another time of need, after World War II.

30 Jeanne Le Hir has noted that, among other possibly very personal inspirations for La jeune fille Violaine and L'Annonce, Claudel may have found a possible impetus in a youthful reading of Zola's novel $\mathrm{La}$ Joie de viure (1889), where the character Pauline radiates goodness, charity, and cheerfulness in the face of the great sadness and the horror of a botched existence, since both women also resuscitate a dead infant. It seems that Violaine plays the same role of relieving pain through charity, but Claudel has shown this dynamic in the context of the Catholic religion, whereas Zola identified it in secular terms $(15-22)$. This mechanism, the reverse effect of the suffering and sacrifice of one as atonement for the mistakes and pains of others, is revealed to an even greater extent in Huysmans' Christian novels than in Claudel's oeurre on the whole.

31 In the trial documentation from Rouen, Jeanne is represented as having said to Robert de Baudricourt in Vaucouleurs, in order to convince him to send her to Chinon to meet the Dauphin:

[...] il n'y personne en effet, ni roi, ni duc, ni fille du roi d'Écosse, ni autre qui puisse recouvrer le royaume de France, et il n'aura de secours, si ce n'est de moi, bien que j'aimerais mieux demeurer à filer auprès de ma pauvre mère, car ce n'est pas mon état, mais il faut que j'aille et je le ferai, puisque mon Seigtd in Pernoud and Clin 33). 